\title{
Anaerobic treatment of pharmaceutical wastewater using packed bed reactor
}

\author{
Mohammed Ali I. Al-Hashimi ${ }^{1}$, Maha I. Al-Ali ${ }^{2}$ and Abbas Hadi Abbas ${ }^{3}$ \\ ${ }^{1}$ Building \& Construction Eng. Dept.; University of Technology. \\ ${ }^{2}$ Lecturer / Chem. Eng. Dept.; Tikrit University. \\ ${ }^{3}$ Lecturer / Environmental Eng. Dept.; Tikrit University.
}

Rec. 14 Aug, 2011 Accpt. 16 Sep, 2011

\begin{abstract}
Typically, pharmaceutical wastewater is characterized by high chemical oxygen demand (COD) concentration, and some pharmaceutical wastewaters can have COD as high as 1100 $\mathrm{mg} / \mathrm{L}$. Due to high organic content, anaerobic technology is a promising alternative for pharmaceutical wastewater treatment. Consequently, in the present study,an anaerobic packed bed reactor was designed and employed to treat highly polluted of pharmaceutical wastewater of Samarra Drug Factory (SDI) in Samarra city (north of Baghdad) in Iraq and suggested to be added to the available wastewater treatment unit of SDI. The efficiency of the anaerobic filter with respect to bed height of filter was studied. The results showed that the first third of filter was the more effective. The filter completed the acclimation period within 34 days in which the COD removal efficiency was $85 \%$. The results also showed that the best hydraulic retention time (HRT) was 24 hours for anaerobic stage and the removal efficiencies of COD and BOD were $87 \%, 90 \%$ for anaerobic stage at the 65 th day of operation.
\end{abstract}

Keywords: Pharmaceutical wastewater, anaerobic treatment, packed bed reactor, COD removal.

\section{Introduction}

Wastes from industries are customarily produced asliquid wastes. (Woodard, 2006). presented a potential hazard to natural water system. Treatment of these wastes is therefore of paramount important. Wastewaters produced from pharmaceutical industries pose several problems for successful biological treatment of (LaPara, 2002). therefore an anaerobic process in many ways is ideal for waste treatment (McCarty P, 1964).

Many reactor configurations are used for the anaerobic treatment of industrial wastes and waste waters. Among them, the most common types are: completely mixed anaerobic digester, up flow anaerobic sludge blanket reactor, fluidized \& expanded bed reactors \& An aerobic filters of (Seghezzo, 1998). Anaerobic digestion is the decomposition of organic and inorganic matter by micro-organisms in the absence of molecular oxygen. It has been used for over a century in the treatment of domestic and industrial wastewaters as(Punal et al.,1999 \& Fernando et al., 2011). Anaerobic packed bed reactor was first proposed as a treatment process by (Young and McCarty P, 1969). The material can be arranged in various confirmations, made out of different matter (plastics, granular activated carbon (GAC), sand reticulated foam polymers, granite, quartz and stone) and can be packed in two configurations (loose or modular). The reactors can be operated in up-flow or downflow feed of (Young \& Kennedy, 1991). mode. (Ince, B K et al., 2002). studied the up flow anaerobic filter of chemical synthesis based pharmaceutical wastewater.

The filter was packed with plastic pall rings have void space of $90 \%$ and specific surface area $205 \mathrm{~m}^{2} / \mathrm{m}^{3}$. They concluded that a maximum of $70 \%$ COD removal efficiency was obtained with a raw pharmaceutical wastewater at an OLR of approximately 7.5 $\mathrm{kg}$ COD. $\mathrm{m}^{-3} \cdot \mathrm{d}^{-1}$ with HRT of 2-3 days.

Two up flow anaerobic sludge blanket (UASB) reactors with different operating temperatures, mesophilic $\left(35 \pm 1^{\circ} \mathrm{C}\right)$ and thermophilic $\left(54 \pm 1^{\circ} \mathrm{C}\right)$ were used by (ISA et al., 2010) to study the treatment of a nonpenicillin based product factory waste water .The organic loading rate varied from 0.07 to $0.45 \mathrm{~kg} \mathrm{COD} \cdot \mathrm{m}^{-3} \cdot \mathrm{d}^{-1}$, the highest percentage of COD removal for the mesophilic and thermophilic reactors was $95 \%$ and $93 \%$ respectively.

(Nandy and kaul, 2001). Studied the upflow anaerobic fixed film reactor for treatment of herbal-based pharmaceutical

* Corresponding author: 
wastewater. The upflow reactor was fabricated from a PVC column of $0.11-\mathrm{m}$ diameter and $2.25 \mathrm{~m}$ height having a total empty volume of $0.0124 \mathrm{~m}^{3}$.The column base was designed to disperse the wastewater flow uniformly. The COD removal efficiencies (76-96) \%were achieved for applying organic Loading rate up to $10 \mathrm{~kg}$ COD. $\mathrm{m}^{-3} \cdot \mathrm{d}^{-1}$, while increasing organic Loading rate to $48 \mathrm{kgCOD} \cdot \mathrm{m}^{-3} \cdot \mathrm{d}^{-1}$ led to COD removal efficiency ranging (46-50) \% $40-50 \%$ While the total COD removal efficiency of the sequential UASB+CSTR treatment system of(Sponza and Demirden, 2007). was determined as $97 \%$.Their results indicated that the system exhibited a good removal performance for sulfamerazine.

(Chen et al., 1994). studied the up flow anaerobic filter for treatment of pharmaceutical wastewater. They used a cylindrical Plexiglas pipe within internal diameter of $0.14 \mathrm{~m}$. Fire expanded clay pellets were used as packing medium filled to a depth of $2 \mathrm{~m}$ with an effective void volume of $15 \mathrm{~L}$. They concluded that when HRT decreased from 20to 2day organic loading rate from 1 to $10 \mathrm{~kg}$ COD. ${ }^{-3} \cdot \mathrm{d}^{-}$ $\left.{ }^{1}\right)$.Anaerobic treatment achieved 93- 70\% COD removal rate. (Hamdy et al., 1992). studied the mesophilic and thermophilic upflow anaerobic filter for treatment of pharmaceutical waste resulted from pharmaceutical plant in Bombay -India, (Sachs et al., 1982). used six Laboratories upflow anaerobic filter for pharmaceutical wastewater treatment while (Jennett \& Dennis, 1975). used four Laboratory filters fabricated of Plexiglas's column .These filters successfully treated pharmaceutical wastewater with 70 to $96.8 \%$ COD removal efficiency ,but (Oktem et al., 2007). study the performance of a lab-scale hybrid upflow anaerobic sludge blanket (UASB) reactor, treating a chemical synthesis-based pharmaceutical waste water, was evaluated under different operating conditions. The hybrid UASB reactor was found to be far more effective at an OLR of $8 \mathrm{~kg}$ COD. $\mathrm{m}^{-3} \cdot \mathrm{d}^{-}$ ${ }^{1}$ with a COD removal efficiency of $72 \%$. As (Morse et al., 2002 and Abbas, 2005). studied the Anaerobic/ Aerobic sequence for treatment of pharmaceutical waste water. Their investigation was amoxicillin that is an antibiotic used by (NASA). The biological components of water recovery system (WRS) were an anaerobic packed-bed reactor and aerobic tubular reactor.

The anaerobic packed-bed reactor reduced total organic carbon (TOC) concentration and denitrifies the wastewater by covering nitrate and or nitrite to nitrogen gas, (Altaf and Ali, 2010). designed a sequential batch reactor after a series of experiments. The effluent met the Pakistan National Environmental Quality Standards specifications after 21days of treatment in the SBR. The changes in $\mathrm{pH}, \mathrm{BOD}$, COD,TDS,TSS,Ammonia levels, Oil and grease levels were found to be significant $(p$ $<0.05)$.

\section{Materials and Method}

Three types of wastewater samples were taken for analysis. The first was untreated wastewater taken from equalization tank of SDF. the second was anaerobic treated taken from anaerobic filter effluent and the third was anaerobic/aerobic wastewater treated taken from acerbic reactor effluent. These tests including $\mathrm{pH}$, temperature, COD, and BOD were tested according to Standard Methods for Examination of (Water and Wastewater, 1985). The discharge of untreated wastewater for the factory also was measured as shown in table (1).

\begin{tabular}{|l|c|c|c|}
\hline Test & Min. & Max. & Average \\
\hline Temp. $\mathbf{C}^{\mathbf{0}}$ & 13.2 & 19 & 16.8 \\
\hline $\mathbf{p H}$ & 7.3 & 7.5 & 7.38 \\
\hline COD mg/l & 400 & 1250 & 668 \\
\hline BOD mg/l & 180 & 360 & 272 \\
\hline $\mathbf{Q ~ m}^{\mathbf{3} / \mathbf{h r}}$ & 14.4 & 33.34 & 18.671 \\
\hline
\end{tabular}

Table. 1. Characteristics \& discharge of untreated wastewater for Samarra Drugs Factory

\section{Experimental Equipment}

Toxic and recalcitrant wastewaters were previously believed not to be suitable for anaerobic processes, were effectively treated as described by (Chelliapan et al., 2011). Since a pilot plant for the upflow anaerobic filter and aerobic reactor as sequential system was built and installed near equalization tank of the factory, as shown in figure (1).

The parts of pilot plant are explained as following:

Up flow Anaerobic Filter.

- Aerobic Stage.

- Hydraulic System

- Ground Tank of 500L volume capacity. 
- Elevated Tank No.1 of 500L volume capacity.

- Elevated Tank No.2 of 250L volume capacity.

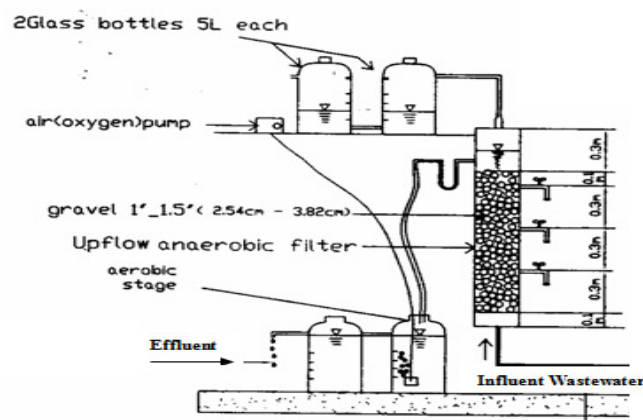

Fig. 1. SchematicDiagram of Upflow Anaerobic Filter - Aerobic Stage

The anaerobic packed bed reactor (Fig. 1) is a PVC cylindrical reactor of external and internal diameters with 0.15 and $0.14 \mathrm{~m}$ respectively was used similar to the model of Jennett and Dennis(1975).Plastic perforated plate screen was placed in the bottom of the pipe $(10 \mathrm{~cm}$ above the base of column) for dispersion the influent wastewater uniformly through its holes upward. Three sample ports were placed at $30 \mathrm{~cm}$ interval throughout column height. These sample ports extended to the center of the column, so that a more representative sample of the filter contents could be obtained. The sample ports were made of $1.27 \mathrm{~cm}$ inside diameter of P.V.C tubing were sealed in to the wall of the column by special kind of glue to give a watertight and prevent probable leakage. The column was filled with $1 \mathrm{~m}$ height by smooth and inert gravel pass sieve opening $2.54 \mathrm{~cm}$ and retain sieve opening $3.82 \mathrm{~cm}$. The volume of packed media was $15.33 \mathrm{~L}$. The gravel was well cleaned by water before placing it into the column. Porosity of this graded gravel was determined practically by using plastic cylinder volume $2 \mathrm{~L}$ and filled with this gravel and then put quantity of water up to the Level of $2 \mathrm{~L}$, the water will occupy the voids of the gravel. By measuring the water volume water graduated glass cylinder and divided this number on the $2 \mathrm{~L}$.It showed that the void ratio was 0.43 .

The filter worked volume was $6.6 \mathrm{~L}$ and the specific surface area per volume ratio was $107.716 \mathrm{~m}^{2} / \mathrm{m}^{3}$ these were calculated by the following equation, (Cheremisinoff et al., 2000):

$\mathrm{V}_{\text {worked }}=\mathrm{V}_{\text {packed meadia }} \times \operatorname{Void}_{\text {ratio }}---(1)$
$\mathrm{AB}=\psi \mathrm{A}(1-\mathrm{e})$

$----(2)$

Where: $A B$ : the surface area presented to the fluid per unit volume of the bed when the particles are packed in a bed $\left(\mathrm{m}^{2} / \mathrm{m}^{3}\right)$

A: the average geometric specific area of the particles $\left(\mathrm{m}^{2} / \mathrm{m}^{3}\right)$ is equal to $(6 / \mathrm{d})$,

d: diameter of particle of packed media,

e: void ratio of packed media.

$\Psi$ : sphericity coefficient $(\psi=1.0$ for sphere particle) the upflow anaerobic filter and aeration system had operated for three runs after 34 days of seeding for reactor startup. Each run had operated for thirty days.COD $\&$ BOD were measured for upflow anaerobic filter and for aerobic stage.

The efficiency of a wastewater treatment process is defined as:

$\mathrm{E}=\frac{\mathrm{S}_{0}-\mathrm{S}_{1}}{\mathrm{~S}_{0}} \times 100 \%$

In which: E: treatment efficiency \%,

So \& S1: influent \& effluent wastewater concentration $(\mathrm{mg} / \mathrm{l})$ respectively.

Hydraulic retention time (HRT) was found to be an important key parameter which can improve the removal rate of all targeted substances Chen (1994).

HRT $=\frac{\mathrm{V}}{\mathrm{Q}}$ $------(4)$

A linear relationship existed between COD removal efficiency and inverse of (HRT) in the void within the rock-filled reactor as shown below Young (1983).

$\mathrm{E}=100 *\left(1-\frac{\varepsilon}{\mathrm{HRT}}\right)$

In which: $\mathrm{E}=\mathrm{COD}$ removal efficiency $\%$, $\varepsilon=$ proportional coefficient $=6(\varepsilon=4$ as Young and McCarty P 1969).

The variation in $\varepsilon$ value was belonging to temperature difference.

\section{Experimental Work}

The reactor operated as startup seeding on a substrata consisting of $1000 \mathrm{mg} / \mathrm{l}$ glucose (stage1) with addition of trace nutrient (phosphates and Nitrates) and initially a feed rate of $3.3 \mathrm{l} / \mathrm{d}(\mathrm{HRT}=48 \mathrm{hr})$, which effects the COD removal (CODr). After the $16^{\text {th }}$ day (stage2), the pharmaceutical wastewater was gradually replaced to ensure acclimatization that achieved in the $34^{\text {th }}$ day (stage 6), table (5).

\section{Results and Discussion}

A100\% pharmaceutical wastewater feeding, three runs with HRT 24, 18, $12 \mathrm{hr}$, 
were used to evaluate the biofilter performance, and each run tasted 30 days. The percentage of removal efficiencies for COD was calculated by using equation (3). These results are shown in the table (2) and graphically represented in figure (2) that showed the change of COD removal efficiency with time progress. It can be noted that the maximum COD removal efficiency (COD \%) was $89 \%$ in the 65th day with HRT $=24 \mathrm{hr}$. This may be attributed to complete of anaerobic attached biofilm.

\begin{tabular}{|c|c|c|c|c|c|c|c|c|c|c|c|c|c|c|}
\hline $\begin{array}{c}\text { Day } \\
\text { s }\end{array}$ & $\underset{\mathrm{mg} / \mathrm{l}}{\mathrm{COD}_{\text {in }}}$ & $\underset{1 / d}{Q}$ & $\begin{array}{c}\text { COD } \\
\mathbf{r} \%\end{array}$ & $\begin{array}{c}\text { BOD } \\
\mathbf{r} \%\end{array}$ & Days & $\begin{array}{c}\mathrm{COD}_{\text {in }} \\
\mathrm{mg} / \mathrm{l}\end{array}$ & $\underset{1 / d}{Q}$ & $\begin{array}{c}\text { COD } \\
\mathbf{r} \%\end{array}$ & $\begin{array}{c}\text { BOD } \\
\mathbf{r} \%\end{array}$ & Days & $\underset{\mathrm{mg} / \mathrm{l}}{\mathrm{COD}_{\text {in }}}$ & $\underset{1 / d}{Q}$ & $\begin{array}{c}\text { COD } \\
\text { r\% }\end{array}$ & $\begin{array}{c}\text { BOD } \\
\mathbf{r} \%\end{array}$ \\
\hline 35 & 980 & 6.6 & 71 & 74 & 70 & 800 & 8.8 & 68 & 73 & 105 & 820 & $\begin{array}{c}13 . \\
2\end{array}$ & 51 & 66 \\
\hline 40 & 960 & $=$ & 75 & 77 & 75 & 820 & $=$ & 64 & 72 & 110 & 840 & $=$ & 50 & 64 \\
\hline 45 & 1000 & $=$ & 77 & 79 & 80 & 840 & $=$ & 61 & 70 & 115 & 830 & $=$ & 48 & 63 \\
\hline 50 & 880 & $=$ & 82 & 84 & 85 & 844 & $=$ & 59 & 70 & 120 & 880 & $=$ & 44 & 60 \\
\hline 55 & 860 & $=$ & 84 & 87 & 90 & 740 & $=$ & 55 & 68 & 125 & 900 & $=$ & 42 & 61 \\
\hline 60 & 750 & $=$ & 86 & 89 & 95 & 860 & $=$ & 54 & 68 & 130 & 1000 & $=$ & 41 & 60 \\
\hline 65 & 760 & $=$ & 87 & 90 & 100 & 880 & $=$ & 53 & 64 & 135 & 1100 & $=$ & 39 & 58 \\
\hline Avg. & 884 & 6.6 & 80 & 84 & Avg. & 826 & 8.8 & 59 & 69 & Avg. & 910 & $\begin{array}{c}13 . \\
2\end{array}$ & 45 & 62 \\
\hline
\end{tabular}

Table. 2. The Removal Efficiencies During (HRT 24, 18 \& 12 h) Anaerobic Treatment

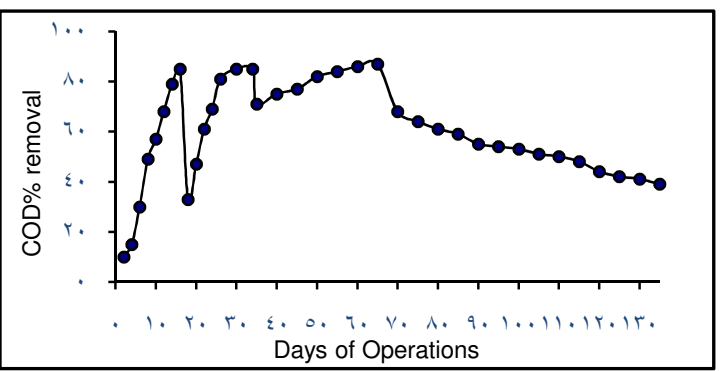

Fig. 2. Effect of HRT on COD and BOD Removal

\section{Effect of Seeding and Startup on COD Removal}

During the startup (acclimation) periods; as shown in table (3) the removal of COD decreased from $85 \%$ in the 16 th day (stage 2 ) of operation to $33 \%$ in the 18 th day (stage 3 ) then it increased up to $81 \%$ in the $26^{\text {th }}$ day (stage 6). The sudden decrease may be attributed to the existence of toxic materials and acidity during the transition stages $(2,3$, 4 and 5).

\begin{tabular}{|c|c|c|c|c|c|c|c|c|c|}
\hline Stage & Days & $\begin{array}{c}\text { HRT } \\
(\text { hr })\end{array}$ & Substrata & $\begin{array}{c}\operatorname{COD}_{\mathrm{r}} \\
\%\end{array}$ & Stage & Days & $\begin{array}{c}\text { HRT } \\
(\text { hr })\end{array}$ & Substrata & $\underset{\%}{\mathrm{COD}_{\mathrm{r}}}$ \\
\hline \multirow[t]{8}{*}{1} & 2 & 48 & $\begin{array}{c}\text { Glucose } \\
100 \%\end{array}$ & 10 & 2 & 16 & 48 & $\begin{array}{c}20 \% \text { waste } 80 \% \\
\text { Glucose }\end{array}$ & 85 \\
\hline & 4 & $=$ & $=$ & 15 & 3 & 18 & $=$ & $\begin{array}{c}40 \% \text { waste } 60 \% \\
\text { Glucose }\end{array}$ & 33 \\
\hline & 6 & $=$ & $=$ & 30 & 4 & 20 & $=$ & $\begin{array}{c}60 \% \text { waste } 40 \% \\
\text { Glucose }\end{array}$ & 47 \\
\hline & 8 & $=$ & $=$ & 49 & 5 & 22 & $=$ & $\begin{array}{c}80 \% \text { waste } 20 \% \\
\text { Glucose }\end{array}$ & 61 \\
\hline & 10 & $=$ & $=$ & 57 & \multirow[t]{4}{*}{6} & 24 & $=$ & $100 \%$ waste & 69 \\
\hline & 12 & $=$ & $=$ & 68 & & 26 & $=$ & $100 \%$ waste & 81 \\
\hline & \multirow[t]{2}{*}{14} & \multirow[t]{2}{*}{$=$} & \multirow[t]{2}{*}{$=$} & \multirow[t]{2}{*}{79} & & 30 & 36 & $100 \%$ waste & 85 \\
\hline & & & & & & 34 & $=$ & $100 \%$ waste & 85 \\
\hline
\end{tabular}

Table. 3. Performance of Packed Bed Reactor During Seeding and Startup

Effect of HRT on COD and BOD Removal

Different HRTs were used to determine practically the COD removal efficiency for each HRT. Table (4) showed the average $\mathrm{COD}_{\mathrm{r}} \%$ with respect to HRT and calculated the proportional coefficient $(\varepsilon)$ according to equation 5 . The average $(\varepsilon)$ is 6.03 , while $(\varepsilon)$ in the study of (Young and McCarty P, 1969) was 4. Figure (3) showed the increase of COD removal efficiency with the increase of HRT (Barr et al.,1996; Chang et al., 2006; Sach E F et al., 1987; Omer et al., 2008 and Selvamurugan et al., 2010). 


\begin{tabular}{|c|c|c|c|}
\hline No. & HRT(hr) & COD r \% & $\boldsymbol{\varepsilon}$ \\
\hline 1 & 36 & 85 & 5.4 \\
\hline 2 & 24 & 80 & 4.8 \\
\hline 3 & 18 & 59 & 7.35 \\
\hline 4 & 12 & 45 & 6.6 \\
\hline \multicolumn{3}{|c|}{ Average } \\
\hline
\end{tabular}

Tables. 4. COD Removal Efficiency with Respect to HRT \& Values of $(\varepsilon)$.

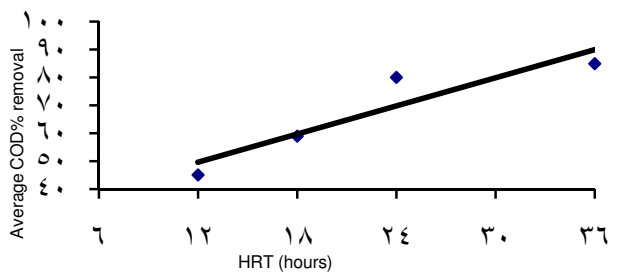

Fig. 3. The Average COD Removal with HRT during Anaerobic Treatment
Behavior of Anaerobic Filter in COD Removal with Respect to the Height.

For evaluating the height behavior of anaerobic filter in $\mathrm{COD} \%$, samples were withdrawn from a filter at a various heights from the ports at $30 \mathrm{~cm}, 60 \mathrm{~cm}, 90 \mathrm{~cm}$, and $100 \mathrm{~cm}$ ) from bottom to top. Tables (5) showed the $\mathrm{COD}_{\mathrm{r}}$ and effluent of COD at different column depths, and they were represented in figures (4) to (9).All figures showed that the lower $30 \mathrm{~cm}$ is the most effective in $\mathrm{COD}_{\mathrm{r}} \%$ (Young et al., 1989 \& Weil et al., 1987).

\begin{tabular}{|c|c|c|c|c|c|c|}
\hline $\begin{array}{c}\text { HRT \& } \\
\text { Influent } \\
\text { COD }\end{array}$ & \multicolumn{2}{|c|}{$\begin{array}{c}\text { HRT=24 (hrs) } \\
\text { Influent COD 760 mg/l }\end{array}$} & \multicolumn{2}{c|}{$\begin{array}{c}\text { HRT=18 (hrs) } \\
\text { Influent COD 800 mg/l }\end{array}$} & \multicolumn{2}{c|}{$\begin{array}{c}\text { HRT=12 (hrs) } \\
\text { Influent COD 820 mg/l }\end{array}$} \\
\hline $\begin{array}{c}\text { Height } \\
\text { (cm) }\end{array}$ & $\begin{array}{c}\text { COD\% } \\
\text { Removal }\end{array}$ & $\begin{array}{c}\text { Effluent } \\
\text { COD mg/l }\end{array}$ & $\begin{array}{c}\text { COD\% } \\
\text { Removal }\end{array}$ & $\begin{array}{c}\text { Effluent } \\
\text { COD mg/l }\end{array}$ & $\begin{array}{c}\text { COD\% } \\
\text { removal }\end{array}$ & $\begin{array}{c}\text { Effluent } \\
\text { COD mg/l }\end{array}$ \\
\hline 30 & 75 & 190 & 65 & 280 & 40 & 492 \\
\hline 60 & 86 & 106 & 66 & 272 & 42 & 476 \\
\hline 90 & 87 & 96 & 67 & 264 & 48 & 430 \\
\hline 100 & 68 & 243 & 68 & 256 & 51 & 405 \\
\hline
\end{tabular}

Table. 5. COD Removal and COD Effluent with Respect to the Height of Anaerobic Filter

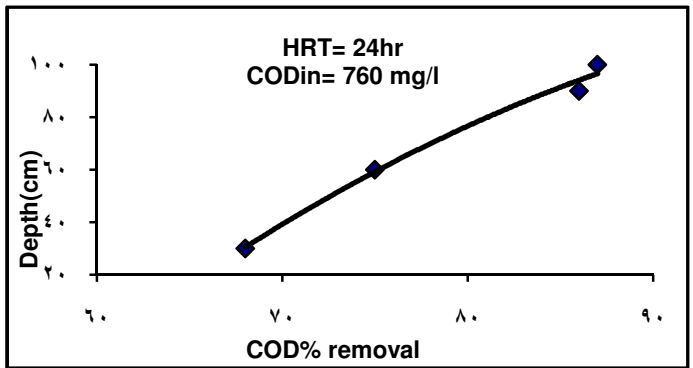

Fig. (4): COD Removal vs. the Depth of the Filter

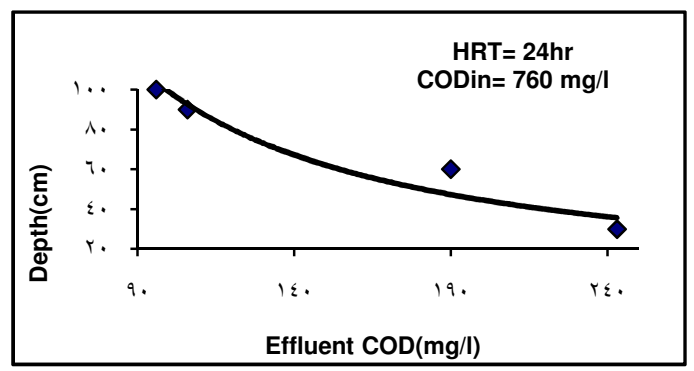

Fig. (5): Effluent COD vs. the Depth of The filter

$\left(1^{\text {st }}\right.$ run $)$ anaerobic treatment $\left(1^{\text {st }}\right.$ run $)$ anaerobic treatment

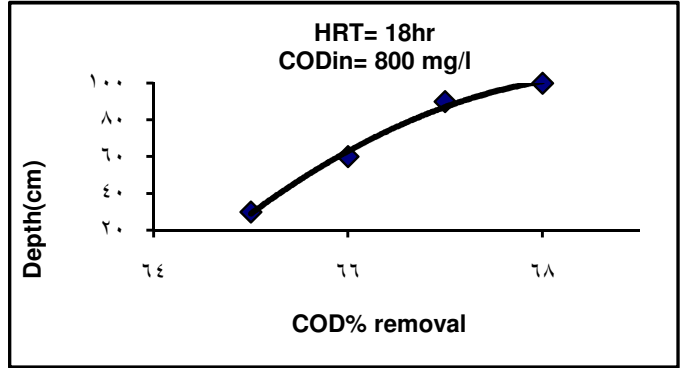

Fig. (6): COD Removal vs. the Depth of the Filter

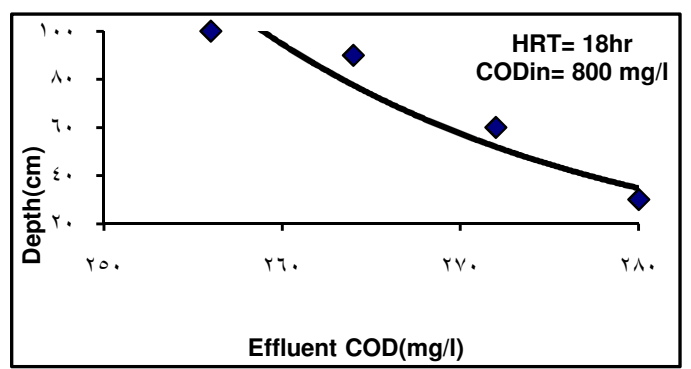

Fig. (7): Effluent COD vs. the Depth of The filter

$\left(2^{\text {nd }}\right.$ run) anaerobic treatment $\left(2^{\mathrm{n}} \quad\right.$ run $)$ anaerobic treatment 


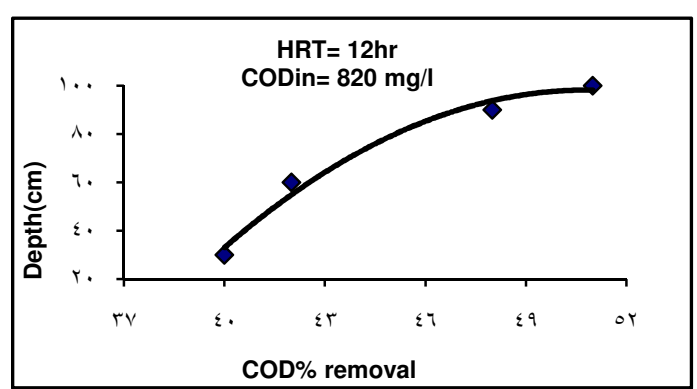

Fig. (8): COD Removal vs. the Depth of the Filter

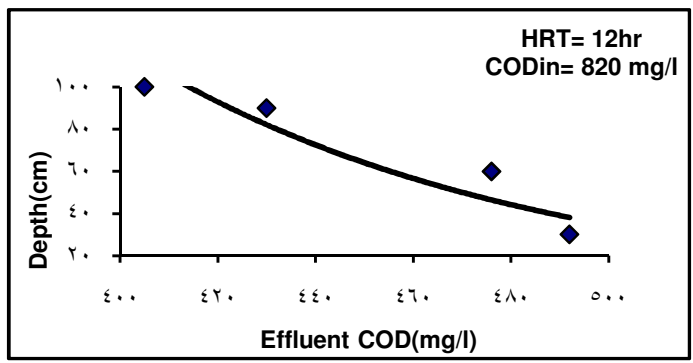

Fig. (9): Effluent COD vs. the Depth of The filter $\left(3^{\text {rd }}\right.$ run $)$ anaerobic treatment $\left(3^{\text {rd }}\right.$ run $)$ anaerobic treatment

\section{Design Steps for Upflow Anaerobic Filter}

Two parallel circulated tank of anaerobic filter are used to improve the treatment process of SDF wastewater. Each has $6 \mathrm{~m}$ in height and $15.4 \mathrm{~m}$ in diameter and filled with gravel (2.54 $3.84 \mathrm{~cm})$. Basic reactor design and operational data for fixed bed reactor are shown in the table (6). (Wales, 1990 \& Coulson et al., 1985).

\begin{tabular}{|l|c|c|}
\hline Description & Unit & Data \\
\hline $\begin{array}{l}\text { Inert material, } \\
\text { type }\end{array}$ & $/$ & Gravel/ plastic \\
\hline $\begin{array}{l}\text { Inert material } \\
\text { diameter }\end{array}$ & $\mathrm{mm}$ & $20-50$ \\
\hline $\begin{array}{l}\text { Inert material, } \\
\text { submerge }\end{array}$ & $\%$ & 100 \\
\hline $\begin{array}{l}\text { Porosity, empty } \\
\text { bad }\end{array}$ & $\%$ & $40-98$ \\
\hline $\begin{array}{l}\text { Porosity, } \\
\text { operation }\end{array}$ & $\%$ & $20-90$ \\
\hline Specific surface & $\mathrm{m}^{2} / \mathrm{m}^{3}$ & $60-200$ \\
\hline Height of reactor & $\mathrm{m}$ & $3-6$ \\
\hline Radius of reactor & $\mathrm{m}$ & $5-20$ \\
\hline $\begin{array}{l}\text { Vertical velocity } \\
\text { empty bed }\end{array}$ & $\mathrm{m} / \mathrm{h}$ & $0.01-0.1$ \\
\hline Table. 6. Technical & $\mathrm{and}$ & \\
\hline
\end{tabular}

Table. 6. Technical and Design Data for Fixed - Bed Anaerobic Fitter

The design steps are shown below.

$Q_{\text {max }}=Q_{\text {peak }}=800 \frac{\mathrm{m}^{3}}{d a y} \quad$ Peak $\quad$ wastewater discharge
HRT $=24 \mathrm{hr}$ (1day)

(Experimental)

Volume of filter $=Q_{\max } \times H R T$

$\therefore \mathrm{V}=800 \mathrm{~m}^{3}$ (equation 4) (Copper et al., 2010).

Use two filters

Each Volume $=400 \mathrm{~m}^{3}$

Use gravel $(2.54-3.82) \mathrm{cm} \quad$ (Experimental)

Gravel void ratio $=0.43 \quad($ Experimental $)$

Worked reactor volume $=400 / 0.43=930 \mathrm{~m}^{3}$

Choose height of filter $5 \mathrm{~m}$

table (5)

Area $=186 \mathrm{~m}^{2}, \mathrm{~A}=\pi r^{2}$,

Thus, $\mathrm{r}=7.7 \mathrm{~m}, \mathrm{~d}=15.4 \mathrm{~m}$

Use $0.5 \mathrm{~m}$ space in the bottom;

And $0.5 \mathrm{~m}$ space in the top of circular tank anaerobic filter.

Total height of filter $=6 \mathrm{~m}$.

Max. COD influent $=1100 \mathrm{mg} / \mathrm{l}$ (Experimental)

Organic load $=Q \times C=400 \frac{\mathrm{m}^{3}}{d a y} \times 1.1 \frac{\mathrm{kg}}{\mathrm{m}^{3}}=$ $440 \frac{\mathrm{kg}}{\text { day }}$

Volumetric Organic load $=\frac{440 \frac{\mathrm{kg}}{\mathrm{d}}}{400 \mathrm{~m}^{3}}$

$=1.1 \frac{\mathrm{kg}}{\mathrm{m}^{3} \cdot \mathrm{day}}$

\section{Conclusion:}

In this research Anaerobic treatment showed more improvement to COD removal reached to $87 \%$ with 24 hours anaerobic HRT treatment in the 65th day of the operation. In packed column the lower third $(30 \mathrm{~cm})$ of upflow anaerobic filter height shows to be the most effective in COD removal and HRT is very important indicator for upflow anaerobic filter in removing COD \&BOD. The removal efficiencies were $87 \%, 90 \%$, achieved respectively in the 65th day of Operation with (HRT $=24$ hrs). It was observed that the removal efficiencies decreased with the decrease of HRT.

\section{References}

Woodard, \& Corran, (2006). Industrial Waste Treatment Handbook, $2^{\text {nd }}$ Ed., Butterworth-Heinemann IS AN Imprint of Elsevier Inc., pp. $(1,83)$.

LaPara, T.M., Nakatsu, CH., Pantea, L.M. and Alleman, J.E. (2002). "Stability of the bacterial communities supported by seven-stage biological process treating pharmaceutical wastewater as revealed byPCR-DGGE," Water Research, vol. 36, pp. 638- 646.

McCarty P, L. (1964). Anaerobic Waste Treatment Fundamentals, Public Works, Vol. 95, No. 9 p.107-112. 
Seghezzo, L., Zeeman, G., van Lier, J.B., Hamelers, H.V.M. and Lettinga, G., (1998). A review: the anaerobic treatment of sewage inUASB and EGSB reactors, Bioresource Technology, vol. 65, pp. 175-190.

Punal, A., Mendez-Pampín, R.J. and Lema, J.M., (1999). A review: The anaerobic treatment of sewage in UASB and EGSB reactors, Bioresource Technology, Vol. 68, Issue 3, pp. 293300.

Fernando, S. and Einschlag, G. (2011). Waste Water - Treatment and Reutilization, JanezaTrdine 9, 51000 Rijeka, Croatia, pp. (4-5).

Young, J. and McCarty P. (1969). The anaerobic filter for waste treatment, "Journal of Water Pollution Control Federation, vol. 41, pp. 160-163.

Young, J.C. (1991). Factors affecting the design and performance of up-flow anaerobic filters," Water Science and Technology, vol. 24, pp. 133-155.

Kennedy, K.J. and Droste, R.L. (1991). Anaerobic wastewater treatment indown-flow stationary fixed film reactors," Water Science and Technology, vol. 24, pp. 157-177.

Ince, B.K., Selcuk, A. and Ince, O. (2002). Effect of chemical synthesis-based pharmaceutical wastewater on performance acetoclastic methanogenic activity and microbial population in upflow anaerobic filter, Journal of Chemical Tech. and Biotechnology, Vol. 77, pp. 711-719.

ISA, M.H., Kutty SH. M. \& Bin Abd Rahim, M.F. (2010). Anaerobic Treatment of Pharmaceutical Wastewater under Mesophilic and Thermophilic Conditions, International Conference on Environment, pp. 1-7.

Nandy, T. and kaul, S.N. (2001). Anaerobic Pretreatment of Herbal Based Pharmaceutical Wastewater Using Fixed Film Reactor with Recourse to Energy Recovery. Journal of water. Res. Vol. 35 No.2, pp. 351-362.

Sponza, D.T. and Demirden, P. (2007). Treatability of sulfamerazine in sequential upflow anaerobic sludge blanket reactor (UASB)/completely stirred tank reactor (CSTR) processes, Separation and Purification Technology, Volume: 56, Issue: 1, pp. 108-117.

Chen, Y.F., Ng, J.W., and Yap, M.G.S. (1994). Performance of Upflow Anaerobic Biofilter Process in Pharmaceutical
Wastewater Treatment, Journal of Res. Cons. and res, PP.83-91.

Hamdy, A.A., Joshi, S.G. and Gupta, S.K. (1992). Effect of organic load and Reactor Height on the performance of anaerobic Mesophilic and Thermophilic fixed film reactor in treatment of pharmaceutical wastewater, Journal of Environmental Technology, Vol.13 pp. 1161-1168.

Oktem, Y.A., Ince, O., Sallis, P., Donnelly, T. and Ince, B.K. (2007). Anaerobic treatment of a chemical synthesis-based pharmaceutical wastewater in a hybrid upflow anaerobic sludge blanket reactor, Bioresource Technology, vol.99, pp. 1089-1096.

Morse, A., Jackson, A., Ken, R. and Pickering, K. (2002). Amoxicillin in Biological water recovery system, CSCE/EWR. ASCE Environmental Engineering Conference Niagara.

Abbas Hadi Abbas, Treatment of Samarra Drugs Factory Wastewater, (2005). M.SC. Thesis, University of Technology,

Altaf, M.S. and Ali, T.A. (2010). Waste Water Treatment Using Sequential Batch Reactor and Development of Microbiological Method for the Analysis of Relative Toxicity, Pakistan Journal of Nutrition, vol.9 no.6, pp. 574-576.

Chelliapan Sh. and Sallis, P.J. (2011). Application of anaerobic biotechnology for pharmaceutical wastewater IIOAB Journal, Vol.2, Issue1; pp. 13-21.

Jennett, C.J. and Dennis, N.D. (1975). Anaerobic Filter Treatment of Pharmaceutical Waste, Journal of water pollution control federation Vol.47. pp. 104-121.

Cheremisinoff, N.P. (2000). Handbook of Chemical Processing Equipment, Butterworth-Heinemann in USA.

Young, J.C. and Dahab, M.F. (1983). Effect of media design on performance of fixedBed anaerobic technology., Journal of Wat. Sci. Tech. Vol. 15 pp. 369-388.

Barr, T.A., Taylor, J.M. and Duff, S.J.B. (1996). Effect of HRT, SRT and Temperature on the Performance of Activated Sludge Reactors Treating Bleached Kraft Mill Effluent, War Res., vol.30, No. 4, pp. 799-810.

Chang, J.S., Changa, C.Y., Chena, A.C., Erdeib, L. and Vigneswaran, S. (2006). Longterm operation of submerged membrane bioreactor for the treatment of high strength acrylonitrile-butadiene-styrene (ABS) wastewater: effect of hydraulic retention time, Desalination, Vol. 191, Issues 1-3, P. 45-51. 
Sach, E.F., Jennett, J.C. and Rand, M.C. (1982). Pharmaceutical waste treatment by anaerobic Filter, Journal of ASCB-EE no. 108 No. EE2. pp. 297-341.

Omer Shareef, K. and Kanmani, S. (2009). Performance Evaluation of Anaerobic Single Baffled Reactor as Alternative to Existing Onsite Sewage treatment for Lakshadweep Island, IPHE Journal, vol.2008, No.1, p. 16-19.

Selvamurugan, M., Doraisamy, P., Maheswari, M. and Nandakumar, N.B. (2010). High Rate Anaerobic Treatment of Coffee Processing Wastewater Using Up flow Anaerobic Hybrid Reactor, Iran. J. Environ. Health. Sci. Eng., Vol. 7, No. 2, pp. 129-136.

Young, J.C. and Yang, B.S. (1989). Design Consideration for Full-Scale Anaerobic Filters, vol.61, no.9, p. 1576-1587.
Weiland, P. \& Braunschweig, (1987). Development of anaerobic filters for treatment of high strength agroindustrial wastewaters, Bioprocess Engineering, vol. 2 39-47.

Walas, S.M. (1990). Chemical Process EquipmentSelection and Design, pp. 433-438.

Couper, J.R., Penney, WR., Fair, J.R. and Walas, S.M. (2010). Chemical Process Equipment Selection and Design, pp. 326,331-334.

Coulson, J.M., Richardson, J.F. (1985). Chemical Engineering, Volum2, Pergamonpresss.

Tchobanoglous, G. and Shroeder, E.D. (1985). Water Quality, Addison-wesley Publishing Company.

\section{المعالجة اللاهوائية لمياه الفضلات الناتجة عن الصناعات الدوائية باستخدام المفاعل اللاهوائي ذو الحثية المياهوة الفضلان

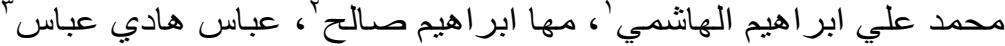

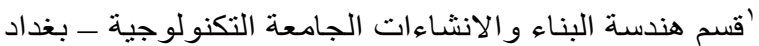

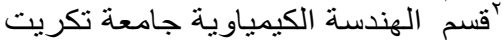

$$
\begin{aligned}
& \text { "قسم هندسة البيئة جامعة تكريت }
\end{aligned}
$$

\footnotetext{
الملخص

تتميز مياه الفضلات الناتجة من الصناعات الدوائية على الأغلب بارتفاع تركيز المتطلب الكيمياوي

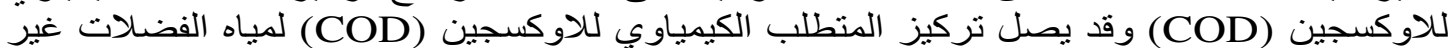

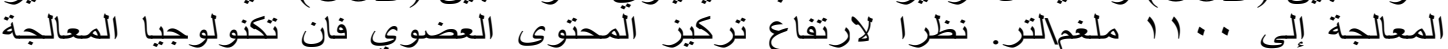

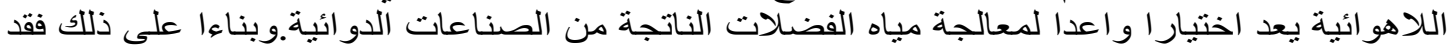

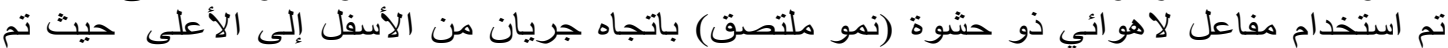

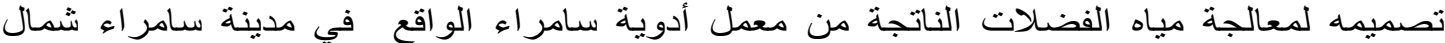

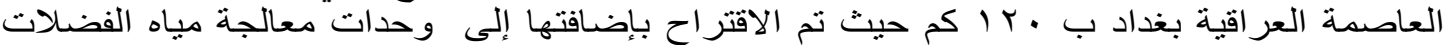

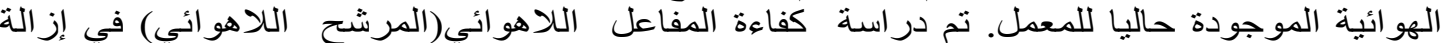

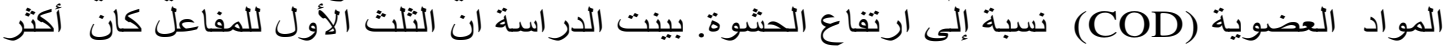

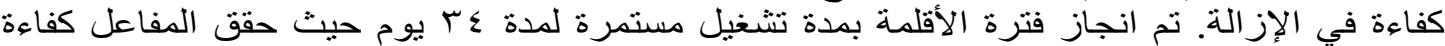

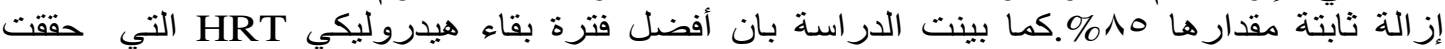

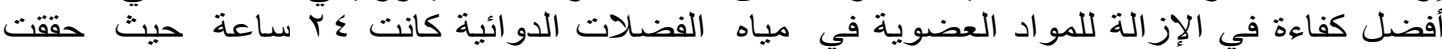

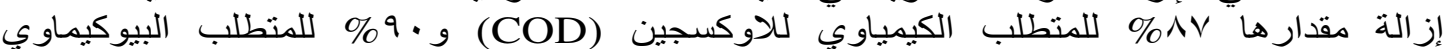

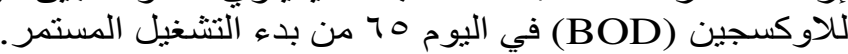

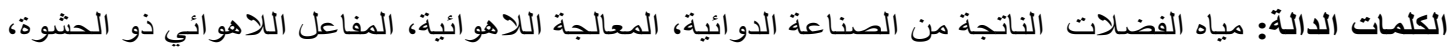
ازاز المتطلب الكيمياوي للاوكسجين.
} 